\title{
ANALISIS VARIASI GENOTIPE IKAN KELABAU (Osteochilus kelabau) DENGAN METODE MITOKONDRIA-RESTRICTION FRAGMENT LENGTH POLYMORPHISM (RFLP)
}

\author{
Mulyasari"), Iskandariah"), Anang Hari Kristanto*"), dan Gleni Hasan Huwoyon") \\ *) Balai Riset Perikanan Budidaya Air Tawar \\ Jl. Raya Sempur No.1, Bogor 16154 \\ E-mail: mulyasari_bogor@yahoo.co.id \\ *) Pusat Riset Perikanan Budidaya \\ Jl. Ragunan 20, Pasar Minggu, Jakarta Selatan 12540
}

(Naskah diterima: 8 Maret 2010; Disetujui publikasi: 27 April 2010)

\begin{abstract}
ABSTRAK
Ikan kelabau (Osteochilus kelabau) adalah salah satu jenis ikan ekonomis penting di perairan Kalimantan yang populasinya menurun. Penelitian ini bertujuan untuk menganalisis variasi genotipe ikan kelabau dengan metode DNA mitokondriaRestrictrion Fragment Length Polymorphism (RLFP) sehingga diperoleh informasi tentang status genotipe ikan kelabau sebagai bahan masukan dalam penentuan pengelolaan ikan tersebut. Hasil menunjukkan bahwa ikan kelabau dari empat lokasi di daerah Kalimantan Barat memiliki variasi genotipe yang rendah dengan komposit haplotipe 0-0,189. Tiga komposit haplotipe terdeteksi dengan menggunakan 5 enzim restriksi yaitu Rsa I, Hae III, Tag I, Hin6 I, dan Alu I pada sekuens 16S-rRNA. Perbedaan yang nyata terlihat antara populasi Sintang dengan populasi lainnya. Jarak genetik terdekat adalah antara populasi ikan kelabau dari Pontianak dengan populasi ikan dari Sekadau, sedangkan jarak genotipe terjauh adalah antara populasi ikan kelabau dari Sintang dengan populasi ikan dari Pontianak dan Sekadau dan ternyata ikan kelabau dari Sintang berbeda spesies dengan yang dari lokasi lainnya.
\end{abstract}

KATA KUNCI: kelabau, Osteochilus sp., Mt-DNA, RFLP

ABSTRACT: Genetic variation analysis of kelabau fish, Osteochilus sp. using DNA Mitochondria-Restriction Fragment Length Polymorphism (RFLP) method. By: Mulyasari, Iskandariah, Anang Hari Kristanto, and Gleni Hasan Huwoyon

Kelabau fish, Osteochilus kelabau is one of economically important fishes from West Kalimantan which is now showing significant wild stock depletion. The objective of this research was to analyze the genetic variation of kelabau fish using DNA mitokondria-Restrictrion Fragment Length Polymorphism (RLFP) method to get information about genetic status of kelabau which will be used for the management of this fish. The result showed that kelabau fish from 4 locations in West Kalimantan has low genetic variation with composite haplotype of 0-0.189. Three composite haplotypes were detected following digestion of 16S-rRNA sequences with five restriction enzymes i.e. Rsa I, Hae III, Taq I, Hin6 I, and Alu I. Significant difference were detected between Sintang population and other populations. Kelabau fish from Pontianak has the closest genetic distance with Sekadau population, meanwhile Sintang population has the furthest genetic distance with population of Pontianak and Sekadau.

KEYWORDS: kelabau, Osteochilus sp., Mt-DNA, RFLP 


\section{PENDAHULUAN}

Ikan kelabau adalah salah satu jenis ikan air tawar yang masuk dalam genus Osteochilus (Kottelat et al., 1993) dan banyak ditemui di wilayah Indonesia antara lain Kalimantan, Sumatera, Jawa, dan Sulawesi. Di perairan Kalimantan, khususnya Kalimantan Barat ikan kelabau terbagi menjadi dua jenis yang dikenal sebagai Osteochilus kelabau dan Osteochilus melanopleura. Ikan kelabau merupakan salah satu jenis ikan asal Kalimantan yang memiliki nilai ekonomis dan potensial untuk dikembangkan. Namun keberadaan ikan kelabau di Kalimantan mengalami penurunan bahkan mendekati kepunahan, oleh karena itu salah satu upaya yang dapat dilakukan untuk melestarikan keberadaan ikan kelabau tersebut adalah dengan domestikasi. Benih yang dihasilkan dari domestikasi tersebut dapat digunakan untuk pengembangan budidaya maupun penebaran kembali (restocking) di perairan di mana populasi jenis ikan tersebut sudah mulai langka (Kartamihardja, 2002).

Dalam pelaksanaan program domestikasi dibutuhkan penyediaan induk yang berkualitas untuk budidaya, tujuannya agar benih yang dihasilkan memiliki kualitas yang unggul dan hal ini berkaitan erat dengan variasi genotipe induk ikan kelabau. Menurut Dunham (2004), variasi genetik/genotipe penting untuk sintasan jangka panjang suatu spesies karena dapat menjamin fitness suatu spesies atau populasi tersebut kemampuan untuk beradaptasi pada perubahan lingkungan. Variasi genetik penting keberadaannya dalam suatu populasi ikan sehingga harus terusmenerus dikelola dan diperbesar agar selalu tersedia bahan untuk meningkatkan stok yang unggul. Oleh karena itu, pengembangan ikan kelabau melalui program domestikasi ini didahului dengan mengumpulkan informasi atau data base genotipe dari spesies ikan kelabau yang ada di Kalimantan. Informasi ini merupakan syarat awal dalam menentukan variasi genotipe atau kekerabatan yang dimiliki ikan kelabau tersebut.

Penentuan variasi genotipe pada ikan dapat dilakukan berdasarkan karakter morfologi dan genotipnya. Secara genotip, variasi genotipe dapat dilakukan melalui pendekatan molekuler dengan berbagai metode salah satunya adalah teknik DNA mitokondria-Restrictrion Fragment Length Polymorphism (RFLP). Penelitian ini bertujuan untuk menganalisis variasi genotipe ikan kelabau dengan metode DNA mitokondriaRestrictrion Fragment Length Polymorphism (RFLP) sehingga diperoleh informasi tentang status genotipe ikan kelabau sebagai bahan masukan dalam pelaksanaan program domestikasi ikan tersebut.

\section{BAHAN DAN METODE}

\section{Ikan Uji}

Ikan yang digunakan untuk analisis mt-DNA adalah ikan kelabau Osteochilus sp. yang diperoleh dari beberapa lokasi di daerah Kalimantan Barat yaitu: Kapuas Hulu, Sintang, Sekadau, dan Pontianak. Sampel yang digunakan untuk penelitian ini masing-masing berjumlah 10 ekor.

\section{Ekstraksi Genom DNA}

Sampel ikan berupa sirip dorsal ditimbang sebanyak 0,5-1 mg dan dimasukkan ke dalam tabung eppendorf 1,5 mL; kemudian dilisis dengan larutan $10 \mathrm{mM}$ tris $\mathrm{HCl} \mathrm{pH} 7,5 ; 125 \mathrm{mM}$ $\mathrm{NaCl}, 10 \mathrm{mM}$ EDTA pH 7,5; 0,5\% SDS dan $4 \mathrm{M}$ urea, sebanyak $500 \mu \mathrm{L}$ dan protein kinase sebanyak $15 \mu \mathrm{L}$. Setelah itu dihomogenkan menggunakan alat vorteks dan diinkubasi pada suhu $37^{\circ} \mathrm{C}$ selama 24 jam.

Selanjutnya ditambahkan larutan Phenol: Chloroform:Isoamilalkohol (PCI) dengan perbandingan 25:24:1 sebanyak $1.000 \mu \mathrm{L}$ dan disentrifuge pada kecepatan $10.000 \mathrm{rpm}$ selama 10 menit. Supernatan lalu dipindahkan ke tabung baru dan ditambahkan etanol 90\% sebanyak $1.000 \mu \mathrm{L}$ dan $\mathrm{Na}$ asetat sebanyak $10 \mathrm{uL}$ dan disentrifuge pada kecepatan 10.000 rpm selama 10 menit. Supernatan dibuang dan pelet dikeringanginkan sampai etanol menguap. Tambahkan DNA rehydration solution sebanyak $100 \mu \mathrm{L}$ dan disimpan pada suhu $4^{\circ} \mathrm{C}$ selama 1 malam (18 jam).

\section{Uji Kualitas DNA}

Uji kualitas DNA dilakukan dengan teknik elektroforesis menggunakan agarose $1 \%$ dan buffer TBE 1x. Elektroforesis berlangsung pada 100 volt selama 30 menit. Hasil divisualisasi menggunakan UV transiluminator.

\section{Amplifikasi DNA dengan Teknik PCR}

Amplifikasi DNA dilakukan menggunakan metode PCR dengan komposisi bahan sebagai berikut: $10 \mu \mathrm{g}$ DNA genom hasil ekstraksi, 10 
pmol setiap primer dan "pure taq DNA" (Amersham Bioscience) yang komposisinya terdiri atas PCR buffer, enzim Taq polymerase, $\mathrm{MgCl}$ dan dNTP mix. Pre-denaturasi dilakukan pada suhu $94^{\circ} \mathrm{C}$ selama 2 menit, sedangkan denaturasi dilakukan pada suhu $94^{\circ} \mathrm{C}$ selama 1 menit, annealing pada suhu $45^{\circ} \mathrm{C}$ selama 1 menit, dan elongasi pada suhu $72^{\circ} \mathrm{C}$ selama 2 menit. Elongasi akhir dilakukan pada suhu $72^{\circ} \mathrm{C}$ selama 7 menit. Proses PCR ini dilakukan sebanyak 35 siklus.

\section{Pemotongan dengan Enzim Restriksi}

Pemotongan DNA dilakukan dengan mencampurkan $0,5 \mu \mathrm{L}$ enzim restriksi, $1 \mu \mathrm{L}$ buffer enzim, $3 \mu \mathrm{L}$ DNA template dan $5 \mu \mathrm{L}$ air dalam microtube 1,5 mL. Campuran tersebut kemudian diinkubasi pada suhu $37^{\circ} \mathrm{C}$ selama 4-24 jam.

\section{Analisis Data}

Susunan haplotipe dari setiap hasil pemotongan dengan enzim restriksi dikumpulkan dan dianalisis dengan program komputer Tools For Population Genetic Analysis (TFPGA) (Miller, 1997). Demikian pula untuk menentukan jarak genotipe dan pembuatan dendrogram dianalisis dengan metode Unweight Pair Group Methods Arithmetic (UPGMA), menggunakan program komputer
Tools For Population Genetic Analysis (TFPGA) (Miller, 1997).

\section{HASIL DAN BAHASAN}

\section{Hasil}

Panjang sekuens Mt DNA 16S-rRNA ikan kelabau yang diperoleh dari hasil PCR mempunyai panjang sekitar 650-700 bp (Gambar 1).

Berdasarkan penelitian, diketahui bahwa dari enam enzim restriksi (Rsa I, Hae III, Taq I, Hin6 I, Hind III, dan Alu I) yang digunakan untuk memotong sekuens Mt-DNA 16S-rRNA ikan kelabau, hanya hind III yang tidak menunjukkan adanya situs pemotongan. Namun dari lima enzim yang memiliki situs pemotongan hanya Hin6 I, Alu I, dan Hae III yang menghasilkan pola polimorfik (Tabel 1).

Pemotongan sekuens Mt-DNA 16S-rRNA menggunakan enzim Rsa I, Alu I, dan Taq I menghasilkan dua pola restriksi (Gambar 2, 3, dan 4), sedangkan enzim Hin6 I dan Hae III menghasilkan tiga pola restriksi (Gambar 5 dan 6). Namun untuk lokasi Sintang, pola restriksi yang dihasilkan oleh enzim Hin6 I hanya dua.

Secara keseluruhan terdapat tiga jenis komposit haplotipe yang diperoleh berdasarkan pola restriksi yang dihasilkan

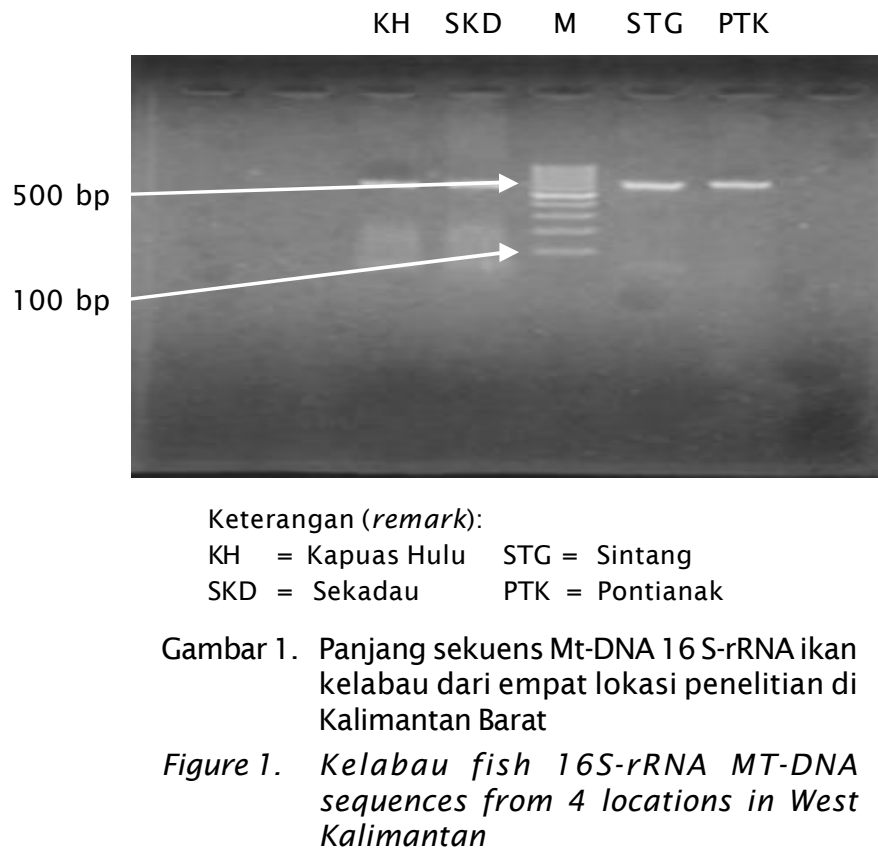


Tabel 1. Jenis enzim restriksi yang digunakan untuk memotong sekuens Mt-DNA 16S-rRNA ikan kelabau

Table 1. Types of restriction enzyme that were used to cut Kelabau fish 16S-rRNA MT-DNA sequences

\begin{tabular}{lcc}
\hline $\begin{array}{c}\text { Jenis enzim rest riksi } \\
\text { Types of rest riction enzyme }\end{array}$ & $\begin{array}{c}\text { Sit us rest riksi } \\
\text { Restriction site }\end{array}$ & $\begin{array}{c}\text { Polimorfik } \\
\text { Polymorphic }\end{array}$ \\
\hline Rsa I & + & - \\
Hae III & + & + \\
Taq I & + & - \\
Hin6 I & + & + \\
Hind III & - & - \\
Alu I & + & + \\
\hline
\end{tabular}

oleh lima enzim restriksi saat memotong sekuens mt-DNA ikan kelabau (Tabel 2). Jumlah haplotipe yang dimiliki oleh lokasi Pontianak, Sekadau, dan Sintang hanya satu. Sedangkan untuk lokasi Kapuas Hulu, lokasi ini memiliki jumlah haplotipe yang paling banyak dibanding lokasi lain yaitu dua jenis haplotipe. Variasi haplotipe yang dimiliki oleh lokasi Pontianak, Sekadau, dan Sintang adalah 0, sedangkan Kapuas Hulu memiliki variasi haplotipe sebesar 0,189. Lokasi Pontianak dan Sekadau hanya memiliki satu haplotipe yaitu AAAAA (komposit haplotipe \#1), demikian pula dengan ikan kelabau yang berasal dari daerah Sintang hanya memiliki haplotipe BABAA (komposit haplotipe \#2). Ikan kelabau di daerah Kapuas Hulu didominasi oleh haplotipe komposit \# 1 yaitu AAAAA $(0,9)$, tetapi memiliki komposit haplotipe lain yaitu komposit haplotipe \#3 atau AAABA $(0,1)$ (Tabel 2).

Berdasarkan hasil uji perbandingan berpasangan Fst (Tabel 3), diketahui bahwa tidak terdapat perbedaan yang nyata $(P>0,05)$ antara populasi ikan kelabau dari Pontianak dengan populasi ikan dari daerah Sekadau dan Kapuas Hulu. Sedangkan antara populasi ikan dari Pontianak, Sekadau, dan Kapuas Hulu dengan populasi ikan dari Sintang terdapat perbedaan yang nyata $(P<0,05)$.

Jarak genetik (D) yang dihitung menurut Wright (1978) modifikasi dari Rogers (1972) dalam Miller (1997) secara komputasi dengan program TFPGA disajikan dalam Tabel 4. Jarak genotipe terdekat adalah antara populasi ikan

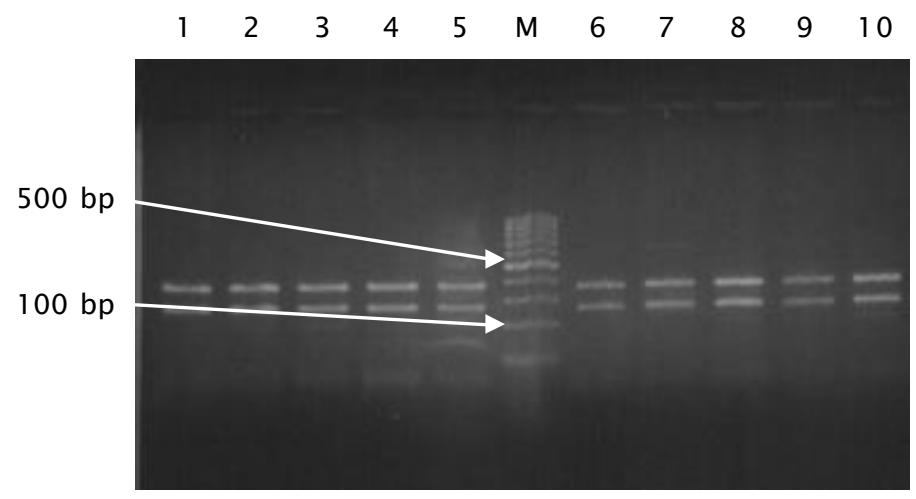

Gambar 2. Pola pemotongan daerah Mt-DNA 16S-rRNA ikan kelabau asal Kapuas Hulu yang direstriksi menggunakan enzim Rsa $I$. M = Marker ladder $100 \mathrm{bp}$

Figure 2. Restriction pattern of kelabau fish 16S-rRNA MT-DNA sequences from Kapuas Hulu that was cut with Rsa I. $\mathrm{M}=$ Marker ladder $100 \mathrm{bp}$ 


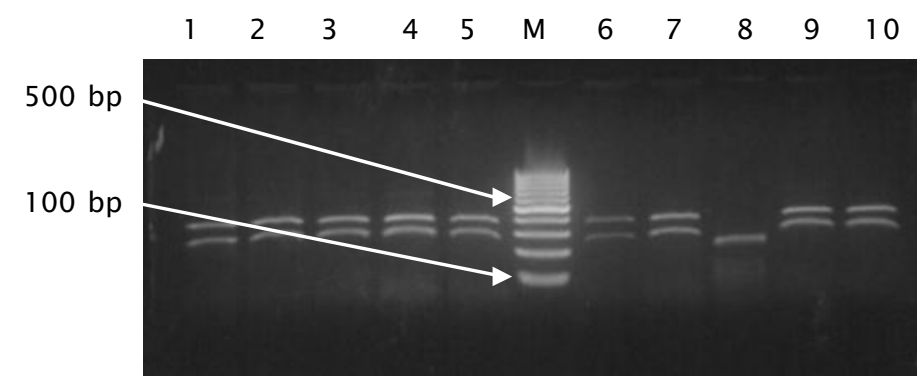

Gambar 3. Pola pemotongan daerah mtDNA D-loop ikan kelabau asal Kapuas Hulu yang direstriksi dengan menggunakan enzim Alu I. M = Marker ladder $100 \mathrm{bp}$

Figure 3. Restriction pattern of kelabau fish 16S-rRNA MT-DNA sequences from Kapuas Hulu that was cut with Alu I. $\mathrm{M}=$ Marker ladder $100 \mathrm{bp}$

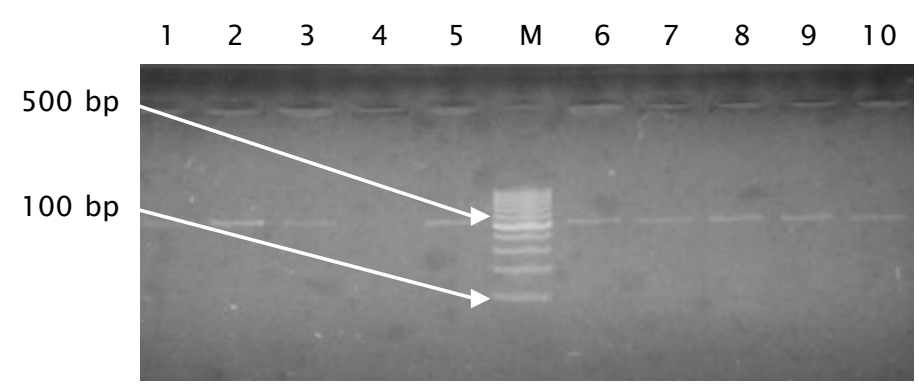

Gambar 4. Pola pemotongan daerah mtDNA D-loop ikan kelabau yang direstriksi dengan menggunakan enzim Taq I. $\mathrm{M}=$ Marker ladder $100 \mathrm{bp}$

Figure 4. Restriction pattern of kelabau fish 16S-rRNA MT-DNA sequences from Kapuas Hulu that was cut with Taq I. $\mathrm{M}=$ Marker ladder $100 \mathrm{bp}$

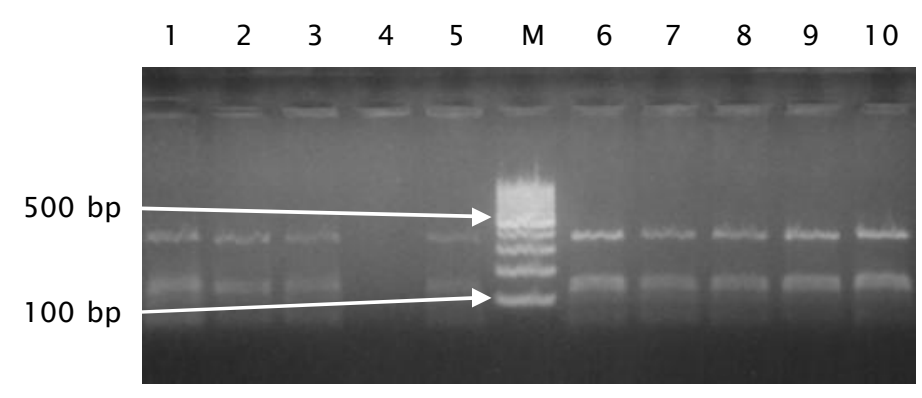

Gambar 5. Pola pemotongan daerah mtDNA D-loop ikan kelabau asal Kapuas Hulu yang direstriksi dengan menggunakan enzim Hin6 $I$. M = Marker ladder 100 bp

Figure 5. Restriction pattern of kelabau fish 16S-rRNA MT-DNA sequences from Kapuas Hulu that was cut with Hin6l. $\mathrm{M}=$ Marker ladder $100 \mathrm{bp}$ 


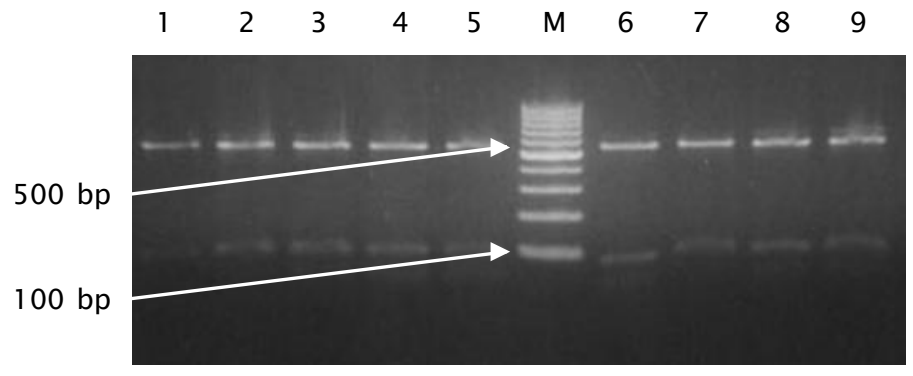

Gambar 6. Pola pemotongan daerah mtDNA D-loop ikan kelabau asal Kapuas Hulu yang direstriksi dengan menggunakan enzim Hae III. M = Marker ladder $100 \mathrm{bp}$

Figure 6. Restriction pattern of kelabau fish 16S-rRNA MTDNA sequences from Kapuas Hulu that was cut with Hae III. M = Marker ladder 100 bp

kelabau dari Pontianak dengan populasi Sekadau $(0,000)$ sedangkan jarak terjauh adalah antara populasi Sintang dengan populasi Pontianak dan Sekadau. Hal ini dapat dilihat lebih jelas dalam bentuk dendrogram yang dihasilkan berdasarkan perhitungan jarak genotipe tersebut (Gambar 6).

\section{BAHASAN}

Ikan kelabau memiliki panjang sekuens MtDNA sekitar 650-700 bp. Ukuran sekuens MtDNA 16S-rRNA pada ikan kelabau ini lebih pendek bila dibandingkan dengan panjang sekuens Mt-DNA 16S-rRNA dari ikan jenis lain seperti lobster air tawar yang memiliki panjang sekuens 600-1.000 bp (Nugroho et al., 2004), baung 1.800-2.000 bp (Nugroho et al., 2005) dan ikan nila 1.200 bp (Arifin \& Kurniasih, 2007). Demikian pula dengan jumlah haplotipe dan nilai variasi haplotipe dari ikan kelabau yang nilainya lebih rendah bila dibandingkan dengan ikan-ikan tersebut. Hal ini menunjukkan bahwa ikan kelabau memiliki variasi genotipe yang rendah dibandingkan dengan jenis ikan air tawar lainnya. Variasi genotipe yang rendah merupakan ciri umum dari jenis ikan-ikan air tawar. Variasi genotipe yang rendah pada ikan kelabau mungkin disebab-

Tabel 2. Frekuensi haplotype mt DNA ikan kelabau yang direstriksi dengan menggunakan 5 enzim restriksi yaitu Rsa I, Hae III, Taq I, Hin6 I, dan Alu I

Table 2. Haplotype frequency of kelabau fish 16S-rRNA MT-DNA sequences that was cut with 5 restriction enzymes i.e. Rsa I, Hae III, Taq I, Hin6 I, and Alu I

\begin{tabular}{|c|c|c|c|c|}
\hline $\begin{array}{l}\text { Jenis haplotipe } \\
\text { Types of haplot ype }\end{array}$ & Pontianak & Sekadau & Sintang & Kapuas Hulu \\
\hline \# 1 AAAAA & 1.00 & 1.00 & - & 0.9 \\
\hline \# 2 BABAA & - & - & 1.00 & - \\
\hline $\begin{array}{l}\text { \# } 3 \text { AAABA } \\
\Sigma \text { Sampel }\end{array}$ & - & - & - & 0.1 \\
\hline $\begin{array}{l}\Sigma \text { Sample } \\
\Sigma \text { Haplotipe }\end{array}$ & 10 & 10 & 10 & 10 \\
\hline $\begin{array}{l}\Sigma \text { Haplotype } \\
\text { Keragaman haplotipe }\end{array}$ & 1 & 1 & 1 & 2 \\
\hline Haplotype diversity & 0 & 0 & 0 & 0.189 \\
\hline
\end{tabular}


Tabel 3. Uji perbandingan berpasangan Fst

Table 3. Pairwise comparison test Fst

\begin{tabular}{lcccc}
\hline \multicolumn{1}{c}{ Populasi } & Pontianak & Sekadau Sintang Kapuas Hulu \\
\hline Pontianak & $* * * *$ & & & \\
Sekadau & 1.0000 & $* * * *$ & & \\
Sintang & $0.0001 *$ & $0.0000 *$ & $* * * *$ & \\
Kapuas Hulu & 1.0000 & 1.0000 & $0.0000 *$ & $* * * *$ \\
\hline P & &
\end{tabular}

kan oleh terbatasnya migrasi ikan kelabau sehingga peluang terjadinya pertukaran gen dengan populasi lain sangat kecil (Nugroho et al., 2005). Di samping itu, rusaknya habitat karena pencemaran lingkungan dan praktek penyetruman menyebabkan populasi ikan kelabau menurun. Jumlah populasi ikan yang terbatas menyebabkan peluang terjadinya perkawinan sekerabat atau inbreeding sangat besar. Hal ini berdampak pada penurunan variasi genotipe suatu jenis ikan. Variasi genotipe yang rendah akan mempengaruhi kemampuan spesies untuk dapat merespon perubahan lingkungan baik buatan maupun yang alami. Setiap kombinasi gen memiliki respon yang berbeda terhadap perubahan lingkungan, adanya variasi gen memberi peluang yang lebih baik untuk merespon perubahan lingkungan (Soewardi, 2007). Variasi genotipe ikan kelabau dari Kapuas Hulu terlihat sedikit lebih tinggi dibanding populasi lain, hal ini kemungkinan karena populasi alam ikan kelabau di daerah ini masih belum banyak terganggu.

Berdasarkan hasil uji perbandingan berpasangan Fst, antara populasi ikan kelabau dari Pontianak dengan populasi ikan dari daerah Sekadau dan Kapuas Hulu tidak terdapat perbedaan yang nyata. Hal ini menunjukkan bahwa populasi ikan kelabau dari ketiga lokasi ini masih merupakan satu keturunan atau satu kerabat. Hal ini terjadi karena adanya genetic introgession ikan kelabau dari Sekadau ke lokasi lain melalui proses restocking. Sedangkan populasi ikan kelabau dari Sintang berbeda nyata secara genotipe dengan populasi ikan dari Pontianak, Sekadau dan Kapuas Hulu. Nilai jarak genotipe dan dendrogram antar populasi ikan kelabau yang diamati, menunjukkan bahwa ikan kelabau asal Sintang memiliki jarak genotipe paling jauh dengan populasi ikan kelabau dari lokasi lainnya yaitu sebesar 0,9539-1. Jarak genotipe ini lebih besar dari jarak genotipe ikan pada spesies yang sama seperti ikan nila (Arifin \& Kurniasih, 2007), ikan batak (Asih et al., 2007), ikan kancra (Nugroho et al., 2005), dan jarak genotipe ikan dari sub spesies yang berbeda seperti ikan baung (Nugroho et al., 2005). Hal ini mengindikasikan bahwa ikan kelabau asal Sintang merupakan jenis yang berbeda dengan populasi ikan kelabau dari lokasi lain.

Berdasarkan pengamatan terhadap morfologi ikan kelabau asal Sintang, terdapat perbedaan warna dan juga sisik dengan ikan kelabau dari lokasi lain (Gambar 8). Ikan kelabau asal Sintang memiliki warna kehitaman, sisik

Tabel 4. Jarak genotipe, D, ikan kelabau dari Pontianak, Sekadau, Sintang, dan Kapuas Hulu

Table 4. Genetic distance, D, of kelabau fish from Pontianak, Sekadau, Sintang, and Kapuas Hulu

\begin{tabular}{lcccc}
\hline \multicolumn{1}{c}{ Populasi } & Pontianak & Sekadau & Sintang & Kapuas Hulu \\
\hline Pontianak & $* * * *$ & & & \\
Sekadau & 0.0000 & $* * * *$ & & \\
Sintang & 1.0000 & 1.0000 & $* * * *$ & \\
Kapuas Hulu & 0.1000 & 0.1000 & 0.9539 & $* * * * *$ \\
\hline
\end{tabular}



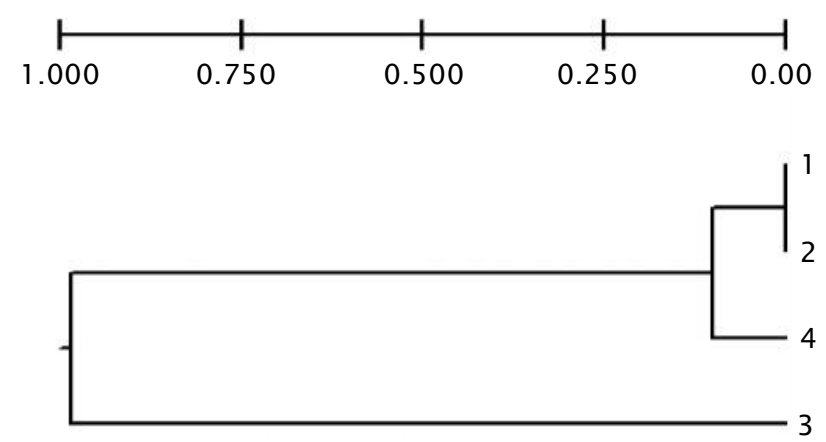

Gambar 7. Dendrogram ikan kelabau dari Pontianak (1), Sekadau (2), Sintang (3), dan Kapuas Hulu (4)

Figure 7. Dendrogram of kelabau fish from Pontianak (1), Sekadau (2), Sintang (3), and Kapuas Hulu (4)

kecil dan bentuk kepala agak rata, sedangkan ikan kelabau dari lokasi lain memiliki warna coklat keabu-abuan, sisik lebih besar, dan bentuk kepala agak melengkung. Identifikasi yang dilakukan terhadap ikan kelabau asal Sintang dan populasi lain menggunakan pengukuran meristik, memperlihatkan bahwa ikan kelabau asal Sintang berbeda spesies dengan ikan kelabau dari Kapuas Hulu, Sekadau, dan Pontianak. Hasil meristik menunjukkan bahwa ikan kelabau asal Sintang termasuk ke dalam jenis Osteochilus melanopleura, sedangkan ikan kelabau dari Kapuas Hulu, Sekadau, dan Pontianak adalah jenis Osteochilus kelabau.

Jarak genotipe atau kekerabatan memberikan gambaran terhadap kemungkinan adanya perkawinan silang. Terkait dengan usaha domestikasi, salah satu aspek yang

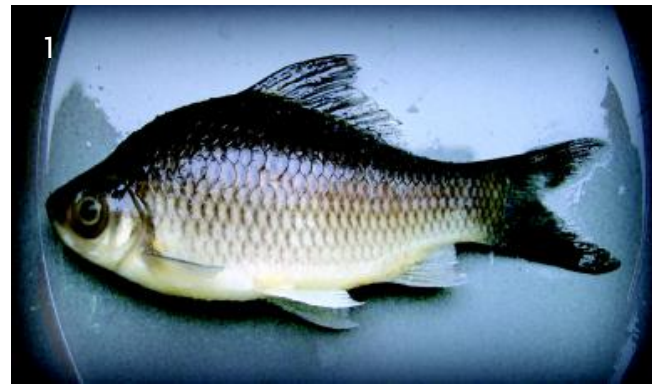

perlu diperhatikan dan berperan penting dalam program domestikasi adalah penyediaan induk yang berkualitas untuk budidaya. Perkawinan antara populasi ikan kelabau dari Kapuas Hulu dengan populasi Pontianak maupun Sekadau memiliki peluang yang lebih besar dalam meningkatkan variasi genotipe ikan tersebut bila dibandingkan perkawinan antara ikan kelabau asal Sekadau dengan Pontianak. Perkawinan yang sekerabat jauh ini diduga juga dapat meningkatkan nilai heterosis keturunan dari populasi yang disilangkan tersebut (Parenrengi et al., 2007). Heterosis adalah kejadian dalam persilangan dimana performa hasil silangannya melampaui performa kedua induknya (Hardjosubroto, 1994). Ikan kelabau asal Sintang juga memiliki potensi untuk dihibrid dengan populasi lain guna meningkatkan variasi genotipe dan nilai heterosis keturunan ikan kelabau ini, meskipun

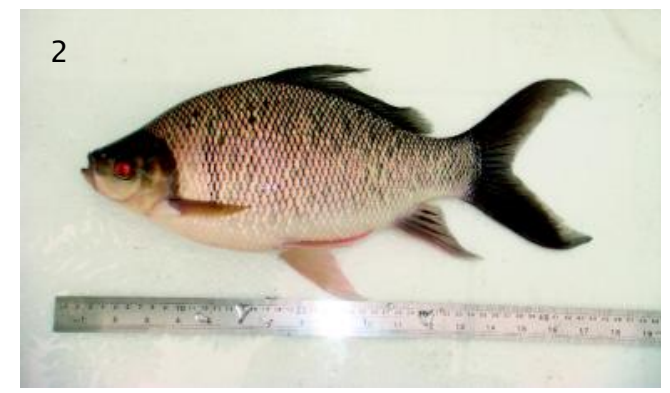

Gambar 8. Bentuk morfologi ikan kelabau (Osteochilus sp.) dari Sekadau (1) dan Sintang (2)

Figure 8. Morphology of kelabau fish (Osteochilus sp.) from Sekadau (1) and Sintang (2) 
ikan kelabau asal Sintang berbeda spesies dengan ikan kelabau dari lokasi lain.

\section{KESIMPULAN}

Berdasarkan hasil analisis DNA mitokondriaRFLP diketahui bahwa variasi genotipe ikan kelabau yang berasal dari Kalimantan Barat tergolong rendah. Ikan kelabau yang berasal dari Sintang memiliki perbedaan genotipe yang nyata dibandingkan dengan ikan yang berasal dari Kapuas Hulu, Sekadau, dan Pontianak. Jarak genotipe terdekat adalah antara populasi ikan kelabau dari Pontianak dengan populasi ikan dari Sekadau, sedangkan jarak genotipe terjauh adalah antara populasi ikan kelabau dari Sintang dengan populasi ikan dari Pontianak dan Sekadau. Ikan kelabau dari Sintang berbeda spesies dengan yang dari lokasi lainnya.

\section{SARAN}

Dalam rangka domestikasi ikan kelabau, untuk menghasilkan variasi genotipe yang lebih tinggi perlu dilakukan perkawinan antara populasi Kapuas Hulu dengan Pontianak maupun Sekadau dan hibridisasi antara ikan kelabau dari Sintang dengan populasi lain mengingat jarak genotipe antara populasi tersebut cukup jauh. Tidak disarankan untuk menyilangkan populasi ikan asal Pontianak dengan ikan dari Sekadau karena jarak genotipenya dekat.

\section{UCAPAN TERIMA KASIH}

Ucapan Terima kasih disampaikan kepada Hibah Diknas Tahun 2009 yang telah membiayai kegiatan penelitian ini. Terima kasih disampaikan pula pada Saudari Sri Sundari yang telah banyak membantu selama penelitian.

\section{DAFTAR ACUAN}

Arifin, O.Z. \& Kurniasih, T. 2007. Variasi genetik tiga populasi ikan nila (Oreochromis niloticus) berdasarkan polimorfisme mtDNA. J. Ris. Akuakultur, 2(1): 67-75.

Asih, S., Nugroho, E., Kristanto, A.H., \& Mulyasari. 2008. Penentuan variasi genetik ikan batak (Tor sorro) dari Sumatera Utara dan Jawa Barat dengan metode analisis Randomly
Amplified Polymorphism DNA (RAPD). J. Ris. Akuakultur, 3(1): 91-97.

Dunham, R.A. 2004. Aquaculture and Fisheries Biotechnology: Genetic Approaches. CABI publishing, UK, '372 pp.

Hardjosubroto, W. 1994. Aplikasi pemuliabiakan ternak di lapangan. Penerbit PT Grasindo, Jakarta, $283 \mathrm{hlm}$.

Kartamihardja, E.S. 2002. Pembukaan lahan gambut di Kalimantan Tengah: mega proyek pemusnahan sumber daya perikanan. Makalah Falsafah Sains, Program Pasca Sarjana Institut Pertanian Bogor. http://rudyct.com/PPS702-ipb/04212/ endi_s_k.htm [September 2009]

Kottelat, M., Whitten, A.J., Kartikasari, S.N., \& Wirjoatmodjo, S. 1993. Fresh water fish of western Indonesia and Sulawesi. Periplus Edition (HK) Ltd, 293 pp.

Miller, M.P. 1997. Tools for population genetic analysis (TFPGA) version 1.3. Department of Biological Science. Northern Arizona University, Arizona, USA, 30 pp.

Nugroho, E., Kurniasih, T., Kusmini, I.I., \& Arifin, O.Z. 2004. Identifikasi dan karakterisasi genetik berbagai jenis lobster air tawar (Cherax sp.) dari Papua. Laporan Akhir Tahun Balai Riset Perikanan Budidaya Air Tawar Bogor Tahun 2004, $10 \mathrm{hlm}$.

Nugroho, E., Hadie, W., Subagja, J., \& Kurniasih, T. 2005. Variasi genetik dan morfometrik pada ikan baung mystus nemurus dari Jambi, Wonogiri dan Jatiluhur. J. Pen. Perik. Indonesia, 11 (7): 1-6.

Nugroho, E., Subagja, J., Asih, S., \& Kurniasih, T. 2006. Evaluasi variasi genetik ikan kancra dengan menggunakan marker mt-DNA Dloop dan Randomly Amplified Polymorphism DNA (RAPD). J. Ris. Akuakultur, 1(2): 211-217.

Parenrengi, A, Sulaeman, Hadie, W., \& Tenriulo, A. 2007. Variasi morfologi udang pama (Penaeus semiculcatus) dari perairan Sulawesi Selatan dan Sulawesi Tenggara. J. Ris. Akuakultur, 2(1): 389-397.

Soewardi, K. 2007. Pengelolaan variasi genetik sumberdaya perikanan dan kelautan. Departemen Manajemen Sumberdaya Perairan, Fakultas Perikanan dan Ilmu Kelautan, Institut Pertanian Bogor, Bogor, $153 \mathrm{hlm}$. 